\title{
First CpG island microarray for genome-wide analyses of DNA methylation in Chinese hamster ovary cells: new insights into the epigenetic answer to butyrate treatment
}

\author{
Anna Wippermann ${ }^{1,2^{*}}$, Sandra Klausing ${ }^{1}$, Oliver Rupp ${ }^{2}$, Thomas Noll ${ }^{1,2}$, Raimund Hoffrogge ${ }^{1}$ \\ From 23rd European Society for Animal Cell Technology (ESACT) Meeting: Better Cells for Better Health \\ Lille, France. 23-26 June 2013
}

\section{Background}

Optimizing productivity and growth of recombinant Chinese hamster ovary $(\mathrm{CHO})$ cells requires insight and intervention in regulatory processes. This is to some extent accomplished by several 'omics' approaches. However, many questions remain unanswered and bioprocess development is therefore still partially empirical. In this regard, the analysis of DNA methylation as one of the earliest cellular regulatory levels is increasingly gaining importance. This epigenetic process is known to influence transcriptional events when it occurs at specific genomic regions with high $\mathrm{CpG}$ frequencies, called $\mathrm{CpG}$ islands (CGIs). Being methylated, CGIs attract proteins with methyl-DNA binding domains (MBD proteins) that in turn can interact with chromatin modifying complexes, thereby leading to a transcriptionally inactive state of the associated gene [1]. In CHO cells, DNA methylation has yet only been investigated in gene-specific approaches, e.g. regarding the CMV promoter [2]. To analyze differential DNA methylation in $\mathrm{CHO}$ cultures on a genomic scale, we developed a microarray covering 19,598 CGIs in the $\mathrm{CHO}$ genome. We applied it to elucidate the effect of butyrate on CHO DP-12 cultures, as this short chain fatty acid (SCFA) is known to elicit epigenetic responses by inhibiting histone-deacetylases [3].

\section{Materials and methods}

Based on the genomic and transcriptomic information available for $\mathrm{CHO}$ cells [4,5], 21,993 promoter-associated and intragenic CGIs were identified in the $\mathrm{CHO}$ genome

\footnotetext{
* Correspondence: anna.wippermann@uni-bielefeld.de

${ }^{1}$ Cell Culture Technology, Bielefeld University, Bielefeld, Germany

Full list of author information is available at the end of the article
}

using an algorithm according to Takai and Jones [6]. We developed a customized $60 \mathrm{~K}$ microarray (printed by Agilent Technologies) covering 19,598 (89\%) of the identified CGIs with an average probe spacing of $500 \mathrm{bp}$. Genomic DNA of each four replicate experimental and reference CHO DP-12 (clone \#1934, ATCC CRL-12445) batch cultures was phenol-chloroform extracted and sheared by sonication. Methylated fragments were enriched using the methyl-CpG binding domain of MBD2 protein fused to the Fc tail of IgG1 (MBD2-Fc protein) coupled to magnetic beads (New England Biolabs). Experimental samples prior to treatment with 3 $\mathrm{mM}$ butyrate $(0 \mathrm{~h})$ as well as 24 hours and 48 hours after butyrate addition were directly compared to the references by two-colour co-hybridizations. Data analysis was carried out upon LOWESS normalization by Student's t-tests with p-values $\leq 0.05$ using the open source platform EMMA2 [7]. Confirmatory COBRA (combined bisulfite restriction analysis) was performed by amplifying a $541 \mathrm{bp}$ fragment of the myc proto-oncogene protein-like gene (Gene ID: 100758352) following bisulfite treatment of genomic DNA using the primers myc_for 5 '-atttggaaggatagtaagtatattggaag-3' and myc_rev 5'- aaataaaactctaactcaccatatctcct-3' and the nested primers myc_for_nested 5' - atagtaagtatattggaaggggagtg-3' and myc_rev_nested 5'- taaaactctaactcaccatatctcctc-3' (oligonucleotides obtained from Metabion). Purified PCR products were digested with BstUI (Fermentas) and separated in agarose gels.

\section{Results}

Butyrate treated CHO DP-12 cultures stopped proliferating and decreasing viabilities could be detected 24 hours upon addition of the SCFA (Figure 1A). Simultaneously, 

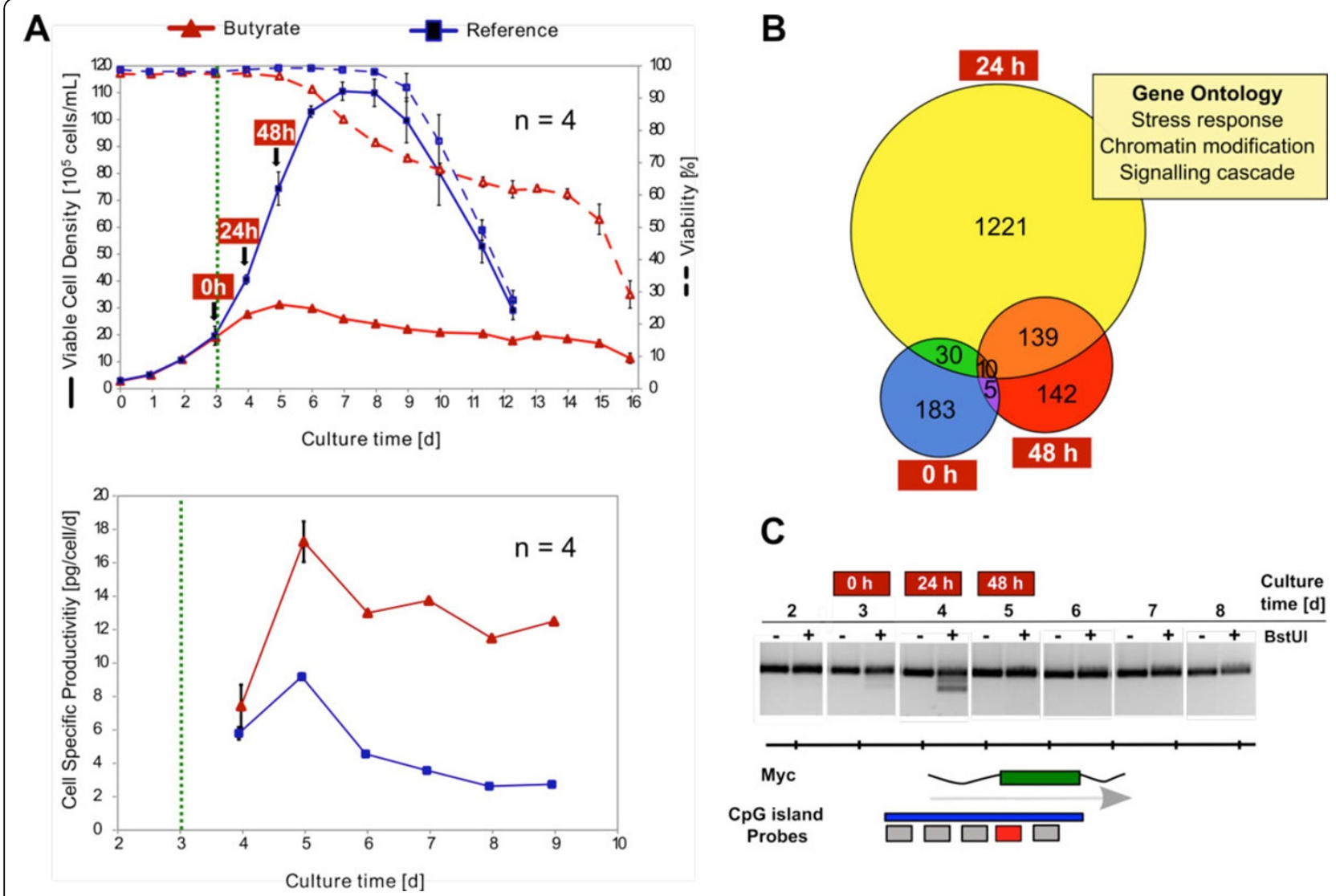

Figure 1 (A) Viable cell densities, viabilities and cell specific productivities for batch CHO DP-12 reference (blue) and butyrate treated (red) cultivations. The green dashed line marks the point of butyrate addition. Error bars represent standard deviations. (B) Venn diagram showing the numbers of genes associated with differentially methylated CpG islands before ( 0 h), 24 hours and 48 hours upon butyrate addition. Gene Ontology classification was performed using DAVID [9] with an EASE score $\leq 0.01$ (C) COBRA analysis of a part of the CGI (blue) of the myc proto-oncogene protein-like gene (green) differential methylation was detected for (red). Cleavage products indicate methylation of BstUl sites in the original DNA.

cell specific productivities increased by nearly $100 \%$ (17 pg/cell/day 48 hours after butyrate addition compared to $9 \mathrm{pg} / \mathrm{cell} /$ day in the reference cultures). Surprisingly, 228 differentially methylated genes could be detected in a comparison between the experimental cultures and the references even before addition of butyrate (Figure 1B), indicating substantial heterogeneity among identically handled parallel cultivations. 24 hours after butyrate addition we found a strongly increased number of 1221, solely at this point in time, differentially methylated genes. Gene ontology classification showed that, amongst others, the terms 'stress response', 'chromatin modification' or 'signalling cascade' were significantly overrepresented. Pathways such as the $\mathrm{Ca}^{2+}$, MAPK and Wnt signalling systems were comprised within the latter group and showed a large coverage by differentially methylated components. 48 hours upon butyrate addition the number of differential methylations decreased by about $90 \%$. COBRA analysis of the Wnt responsive myc proto-oncogene protein-like gene showed clearly detectable cleavage products (indicating methylation of the BstUI sites in the original DNA) 24 hours upon butyrate addition, that completely vanished another 24 hours later (Figure 1C), confirming the results of the microarray analysis.

\section{Conclusions}

Our first genome-wide screening for differential DNA methylation in $\mathrm{CHO}$ cells shows that the epigenetic response upon butyrate treatment seems to be highly dynamic and reversible. This was confirmed by applying the bisulfite-based single-gene method COBRA to analyze a region of the myc proto-oncogene protein-like gene. Furthermore, detection of differential methylation before butyrate addition indicates that heterogeneity in DNA methylation occurs even if cells originated from the same preculture and were treated identically. This occurrence of differentially methylated genes in parallel cultivations strongly fosters the hypothesis that the culture history influences final process outcomes [8]. It underlines the importance of DNA methylation analyses in $\mathrm{CHO}$ cells, 
especially considering the fact that DNA methylation patterns can remain stably anchored over several generations.

\section{Authors' details}

${ }^{1}$ Cell Culture Technology, Bielefeld University, Bielefeld, Germany. ${ }^{2}$ Center for Biotechnology, Bielefeld University, Bielefeld, Germany.

Published: 4 December 2013

\section{References}

1. Ndlovu MN, Denis H, Fuks F: Exposing the DNA methylome iceberg. Trends Biochem Sci 2011, 36:381-387.

2. Osterlehner A, Simmeth S, Göpfert U: Promoter methylation and transgene copy numbers predict unstable protein production in recombinant Chinese hamster ovary cell lines. Biotechnol Bioeng 2011, 108:2670-2681.

3. Mariani MR, Carpaneto EM, Ulivi M, Allfrey VG, Boffa LC: Correlation between butyrate-induced histone hyperacetylation turn-over and cmyc expression. J Steroid Biochem Mol Biol 2003, 86:167-171.

4. Xu X, Nagarajan H, Lewis NE, Pan S, Cai Z, Liu X, Chen W, Xie M, Wang W, Hammond S, Andersen MR, Neff N, Passarelli B, Koh W, Fan HC, Wang J, Gui Y, Lee KH, Betenbaugh MJ, Quake SR, Famili I, Palsson BO, Wang J: The genomic sequence of the Chinese hamster ovary (CHO)-K1 cell line. Nat Biotechnol 2011, 29:735-741.

5. Becker J, Hackl M, Rupp O, Jakobi T, Schneider J, Szczepanowski R, Bekel T, Borth N, Goesmann A, Grillari J, Kaltschmidt C, Noll T, Pühler A, Tauch A, Brinkrolf K: Unraveling the Chinese hamster ovary cell line transcriptome by next-generation sequencing. J Biotechnol 2011, 156:227-235.

6. Takai $\mathrm{D}$, Jones $\mathrm{P}$ : The $\mathrm{CpG}$ island searcher: a new WWW resource. In silico biology 2003, 3:235-40.

7. Dondrup M, Albaum SP, Griebel T, Henckel K, Jünemann S, Kahlke T, Kleindt CK, Küster H, Linke B, Mertens D, Mittard-Runte V, Neuweger $H$, Runte KJ, Tauch A, Tille F, Pühler A, Goesmann A: EMMA 2-a MAGEcompliant system for the collaborative analysis and integration of microarray data. BMC Bioinformatics 2009, 10:50.

8. Le H, Kabbur S, Pollastrini L, Sun Z, Mills K, Johnson K, Karypis G, Hu WS Multivariate analysis of cell culture bioprocess data-lactate consumption as process indicator. J Biotechnol 2012, 162:210-23.

9. Huang DW, Sherman BT, Zheng X, Yang J, Imamichi T, Stephens R, Lempicki RA: Extracting biological meaning from large gene lists with DAVID. Curr Protoc Bioinformatics 2009, Chapter 13, Unit 13.11.

doi:10.1186/1753-6561-7-S6-05

Cite this article as: Wippermann et al:: First CpG island microarray for genome-wide analyses of DNA methylation in Chinese hamster ovary cells: new insights into the epigenetic answer to butyrate treatment. BMC Proceedings 2013 7(Suppl 6):05.

\section{Submit your next manuscript to BioMed Central and take full advantage of:}

- Convenient online submission

- Thorough peer review

- No space constraints or color figure charges

- Immediate publication on acceptance

- Inclusion in PubMed, CAS, Scopus and Google Scholar

- Research which is freely available for redistribution

Submit your manuscript at www.biomedcentral.com/submit
Ciomed Central 